\title{
Human Enhancement Ethics and Uncertainty
}

\author{
GRZEGORZ HOLUB \\ The Pontifical University of John Paul II, ul. Kanonicza 9, 31-002 Krakow, Poland \\ Email: grzegorz.holub@upjp2.edu.pl
}

\begin{abstract}
This article deals with some uncertainties associated with human enhancement ethics. It presents the latter as a kind of a narrative made up of scientific and philosophical concepts. In the paper it is shown that scientific notions underpinning the human enhancement tendency are burdened with a substantial level of uncertainty, especially when the radical enhancement is considered. On the level of philosophical thinking, we encounter many unresolved questions concerning the understanding of the good and our post human destiny, namely who we want to become and why. This amounts to a high level of uncertainty. However, uncertainties are not utterly useless and destructive. They can play roles of stimulating factors or, at least, they can be helpful in discovering new horizons for our existence. In some situations they can also lead us to realize and appreciate what we possess already.
\end{abstract}

Keywords: human enhancement, narrative, ethics, human destiny, uncertainty

\section{INTRODUCTION}

In the course of the development of philosophical ideas, complex philosophical projects have been formulated and, in a sense, they can be treated as a philosophical narrative ${ }^{1}$. Usually they are associated with figures of great philosophers who laid foundations for them. Thus Plato and Aristotle, David Hume and Immanuel Kant can be considered as fathers of such narratives, which, subsequently, have been developed and advanced over longer periods of time by their followers. Within such narratives, philosophers asked many vital questions and proposed new answers and solutions to them. Also, a great deal of attention has been given here to morality and ethics. We can even say that every philosophical narrative has worked out its own pattern of ethical thinking, which today is an indispensable component of contemporary handbooks of ethics. At any rate, such long-standing narratives with their respective achievements should be considered as great narratives.

1 M.-L. Ryan points to a phenomenon of "narrative turn in humanities" in recent years. Of course, "narrative" comes originally from literature meaning by that stories about people, their relationships, their problems, conflicts and experiences (see Ryan 2007: 22ff). In philosophy we can employ this term only in an analogous way, namely, as a synonym of a philosophical project giving us a specific account of reality and its vital segments. 
At present, we increasingly deal with small narratives, which have different characters in comparison to those great ones. They often have short-term lives and their relationships to rational concepts and objective facts are less strict. Small narratives in their extreme version have to do with a concept of "post-truth" as announced by the Oxford English Dictionary as the Word of the Year 2016. In this case, post-truth is understood as "relating to or denoting circumstances in which objective facts are less influential in shaping public opinion than appeals to emotion and personal belief" (Oxford English Dictionary 2016). Narratives underpinned by post-truth logic can be parts of various ideologies and even mass media coverage. Although they can be characterized as ad hoc and temporary constructions, they do inspire choices and attitudes, including those moral ones.

In contemporary philosophy and science there is a debate on human enhancement. It concerns a wide spectrum of various interventions aimed at a positive modification of human life. Adherents of human enhancement consider such possibilities as prolongation of human biological life, increase of the level of human intelligence, designing of personality traits in embryos and foetuses according to chosen patterns, modification of human moral behaviour by the elimination of certain genes (e.g. an aggression gene) or application of psychoactive drugs aimed at stabilizing and strengthening mental operations. Thus, human enhancement debates draw on the newest discoveries in genetics, genetic engineering and pharmacology. Here there are many speculations concerning future discoveries in biomedical sciences as well. Such debates do also make strong references to philosophical ideas and projects, having to do with ontology, epistemology, philosophy of the human being and ethics. We can ask: What kind of a narrative is present in the human enhancement debate? Is this a part of great or small narratives? We will attempt to answer this question at the end of the paper.

To talk about uncertainty is not an easy enterprise because the term may be used in various disciplines. In this paper, we are not to delve into a psychological aspect of uncertainty; nor are we to touch on the term appearing in social sciences (e.g. education studies or sociology). Rather, we are to be concerned with uncertainty strictly associated with rational concepts, be they scientific or philosophical ones. In this sense, we can contend that usually ethics of great narratives bring with them a low level of uncertainty because of a well-defined set of ideas and methods. Small narratives in turn offer a high level of uncertainty of this kind, although - at the same time - they can offer a low level of psychological uncertainty. What about human enhancement ethics? What amount of uncertainty does it generate? It will be a task of the paper to answer the question or - at least - to shed some important light on that. And one more preliminary remark: talking about uncertainty is strictly associated with certainty; they seem to be sides of the same coin, which accompany each other all the time. Thus, our analyses concerning uncertainty are analyses about certainty as well.

\section{SCIENCE-RELATED UNCERTAINTIES}

Human enhancement ethics draws strongly upon scientific discoveries concerning human biological life; the latter constitute an objective hard core of the whole debate. Without them, all consideration of this kind would amount to pure speculations of a futuristic character or would have to do with subjective projections only. Hence, it is reasonable to consider a level of uncertainty associated with scientific factors present here. Of course, we cannot delve into specific empirical facts because their number and complexity are very advanced and still progressing. We should rather limit our perception to a general scientific horizon. Generally speaking, it is marked by facts that belong to biomedical sciences, i.e. biology and its derivatives (e.g. genetics, cell biology, physiology, neurology, pharmacology). 
The latter disciplines bring with them a certain level of uncertainty because they are still in their dynamic development and none of their present achievements can be treated as definitive and concluding. New research usually supplies new findings and these sooner or later contribute to a whole overhaul of a given theory and its subsequent modification. In a sense, that is what an in-built logic of exact sciences is all about, namely that all pertinent scientific statements must be prone to be falsified, as K. Popper convincingly proved (Popper 2012: ch. 4). Hence, we can contend that a good number of discoveries in biomedical sciences have probabilistic characters. However, what has been proved scientifically so far makes us more conscious of the biological structures and dynamisms even if later it is falsified and considered incomplete. Usually, a former scientific theory is incorporated in the new one, which explains more adequately a given subject and sheds more light on empirical occurrences. From a practical point of view, we know that there is a clear progress in acquiring knowledge on how our biology works and on how we can control its functioning better. Thus, even if we are still uncertain as to a whole truth about, for instance, our genetic make-up, the level of uncertainty is lower from year to year.

Some human enhancement ethicists treat these scientific facts in a very optimistic way. For instance, J. Harris and A. de Grey claim that we can expand our normal lifespan beyond its limits and in this way reach, in the future, an age of 150 and even 1,000 years. Harris claims that "if we were able to combine regenerative treatments of diseases of old age with the ability to switch off the aging process in cells, even longer and healthier life expectancy might be achieved" (Harris 2007: 52). This way of reasoning goes well beyond what current scientific achievements allow us to claim. We are at the beginning of the implementation of regenerative medical findings; we are able to grow some tissues and simple organs (e.g. trachea) but how far we can proceed with such growth procedures is still unknown. As to the ability of switching off the aging process in cells, there are also many unknowns because of the complexity of cell structure ${ }^{2}$. What we know for sure is that genetics is going in the direction of deciphering that complexity and we can entertain some hope associated with that but we cannot say anything definitive about possibilities indicated by Harris. Thus, huge expectations are mixed with some uncertainties; sticking to mere scientific findings recommends us at most a modest certainty.

Far-reaching analyses concerning intelligence are conducted by N. Bostrom. He considers prospects of creating superintellingence starting from our current state of intelligence and ending in a very advanced state of machine-like intelligence. He puts it very tellingly in this way, "if some day we build machine brains that surpass the human brain in general intelligence, then this new super intelligence could become very powerful. And, as the fate of the gorillas now depends more on us humans than on the gorillas themselves, so the fate of our species would depend on the actions of the machine super intelligence" (Bostrom 2014: V). At the same time, Bostrom is quite cautious as to the precise description of that latter situation. Because of many scientific unknowns talking about "the intelligence explosion", he uses such expressions as "a dense mist of uncertainty" or "perplexity and uncertainty" (Bostrom 2014: 314ff).

Bostrom concludes his very interesting considerations with such a prophetic picture, "before the prospect of an intelligence explosion, we humans are like small children playing

2 For instance, E. Postigo Solana claims that the complexity of a cell is so high that what we can plausibly sustain at the current level of research is a retardation of aging processes but not their elimination (see Postigo Solana 2009: 274). 
with a bomb. Such is the mismatch between the power of our plaything and the immaturity of our conduct. Super intelligence is a challenge for which we are not ready now and will not be ready for a long time. We have little idea when the detonation will occur, though if we hold the device to our ear we can hear a faint ticking sound" (Bostrom 2014: 319). This "prophecy" makes us realize that we do not know when and how the intelligence explosion will take place. Thus we are shrouded in a cloud of uncertainty because our current predictions, based on scientific findings, are quite imprecise. However, the picture of "small children playing with a bomb" is quite ambiguous. On the one hand, it reveals our lack of precise knowledge concerning that radically advanced state of intelligence, but on the other, the picture suggests our deeper ignorance and disorientation. Children usually are unaware that something is a dangerous bomb. They tend to treat it as a novel and interesting toy. Bostrom employs a kind of thought experiment but what weakens it is a number of metaphorical and futurological pictures.

\section{PHILOSOPHICAL UNCERTAINTIES}

Adherents of human enhancement try to formulate various philosophical reasons aimed at justifying this enterprise and provide rationale of why to go this direction at all. This philosophical approach is even more in the centre of attention because respective biomedical sciences do not yet offer ready-made ways of improving our human condition and, as we have mentioned, there are many ambiguities concerning their future discoveries in this respect. Moreover, we do not know how a whole process of application of the latter will look like in the light of yet existing ways offered by medicine, education strategies and other traditional human enhancement techniques (e.g. mass media, penitential systems, etc.) ${ }^{3}$. Generally speaking, it is necessary to clarify, as far as possible, a theoretical dimension of the human enhancement debate before we reach a moment when biomedical sciences and technologies give us practical possibilities of interventions. Of course, a number of philosophical concepts coming into play is quite large. We will concentrate only on some of them, especially on the key ethical concept of the good and the human fulfilment.

One of the fundamental reasons presented by human enhancement adherents is a thesis that this kind of intervention brings with it a betterment of the world. For instance, J. Harris reasons in the following way, "it is significant that we have reached a point in human history at which further attempts to make the world a better place will have to include not only changes to the world, but also changes to humanity, perhaps with the consequence that we, or our descendants, will cease to be humans in the sense in which we now understand that idea" (Harris 2007: 3). Thus, an important concept of the good appears here but rather in an unclear context. In the light of Harris' declaration, it looks like what really matters is the betterment of the world and changes introduced into humanity are the only means of achieving this. As a consequence, humans can be transformed into post-human creatures, meaning by that entities more advanced in their powers and faculties, and this will be a part of enhancing the world itself. However, at the centre of attention is not so much human improvement but improvement of the world. Maybe J. Harris wants to avoid an anthropocentric stance but

3 In the case of the so-called moral biomedical enhancement, I. Persson and J. Savulescu voice their caution in the following way, "it is also too early in the day to tell what a programme of more extensive moral bioenhancement could look like and how it could be fitted in with more thoroughgoing traditional moral education and with various possible reforms of law and other social institutions" (Persson, Savulescu 2012: 11). 
the concept of the good is here unclear and this brings with it some uncertainty as to the main direction of postulated changes ${ }^{4}$.

We can indeed put the human good in the centre of our analyses and consider subsequent interventions in the light of that important notion; but even then, there are many uncertainties as to the content of that notion. In fact, it is one of the longest discussed terms in the history of philosophy and hence its complexity. In human enhancement debates, the good of the human being is rather associated with particular traits be they biological or psychological, the latter including the so-called personal characteristics ${ }^{5}$. Thus, a resulting tendency, which is typical of naturalistic philosophy, will be leading to an increase and strengthening of those traits and characteristics, in this way to guarantee a higher level of the quality of human life, understood indeed as a better life. J. Glover discussing this tendency, within a scenario of designer babies, voices one important concern, "the moral requirement to aim for a child who will have the best possible life is an open-ended one, which may place too great a burden on potential parents" (Glover 2006: 54). The reason for that is that we do not know exactly what "the best life" means. Naturalistic philosophers, involved in this discussion, use projective definitions of the good and introduced by them suppositions suggest what that good is ${ }^{6}$. Consequently, its derivative (the best life) is an open-ended concept which is a subject of never-ending discussions and, in some extreme cases, can be even understood in a way which will result in being harmful for a future human individual. F. Kamm points out that a number of factors which must be taken into account while thinking about human enhancement usually goes beyond the understanding and proper appreciation of average people (Kamm 2005: 13). Thus, apprehending and fostering of human good must be approached with great caution and such a move understandably brings with it a fair amount of uncertainty.

Adherents of human enhancement usually argue for an intentional change of the human condition assuming that we, human beings, undergo the change nonetheless. Thus a change is an irremovable element of our existence in this world. Such a mindset is voiced, for instance, by J. Harris who advocates that we "take Darwinian evolution into our intelligent hands". He stresses that "this new process of evolutionary change will replace natural selection with deliberate selection, Darwinian evolution with "enhancement evolution" (Harris 2007: 4). However, some consequences stem from that. Besides the intentional character of the latter, there is one more essential difference: implementation of the enhancement evolution brings with it quick results and changes, with all unexpected side-effects. In comparison to that, the Darwinian evolution worked for that set of outcomes over thousands of years and there has been time

4 For instance, a quite possible tension may arise between the good of the world and the good of the human being. In some situations there is no possibility to promote both and one should be carried out at the expense of the other. It can happen - especially as the results of proposals of some environmental ethicists - that the good of the world is advanced at the expense of the human good but then there is no place for human enhancement at all.

5 Such a focus on the good can be treated as one-sided. Depending on the ontological concept of the human being (e.g. accepting the position of the ontological personalism) we can enrich that approach by distinguishing "the essential good of the person" from "goods for the person". The former is associated with the existence of the person as such; the latter is concerned with a set of goods helping the person to reach his/her fulfilment (see Holub 2016: 178f).

6 Additionally, it seems that those definitions contain a structural error ignotum per ignotum: what is unclear, is to be defined by other unclear thing. For instance, the good is to be understood by enhancement, enhancement in turn by a change in intelligence, and so on. 
for adoption to new conditions, including containing or attenuating negative side-effects by human individuals. Although novel and attractive, the enhancement evolution introduces a quite high level of uncertainty.

Nevertheless, changing of the human condition is not an easy enterprise as far as philosophical concepts are concerned. If we think about a change, usually we want to know two stages of it, namely its outset and outcome. The former is within our cognitive abilities and we are relatively familiar with it; the latter is more problematic and the above-mentioned uncertainties about the concept of the good supply us with some examples. In fact, we stand here before a problem of human or post human fulfilment, which constitutes a very fundamental and complex problem. We can ask: What is a destination point of enhancement procedures? Who are we to become after an intentional implementation of the newest procedures of biomedical findings? Adherents of human enhancement give us rather general answers such as improved humans, post-humans, trans-humans or maybe a singularity, as proposed by R. Kurzweil (Kurzweil 2005) ${ }^{7}$.

As far as those more radical answers are concerned, we can reasonably suspect that there cannot be a defined and a clear-cut destination point. N. Agar considers that scenario under such headings as "unending enhancement" or "enhancement ad infinitum". Let us assume that a present state of our humanity is treated as a preliminary stage to further improvements; from a perspective of radical enhancement, it can be called as a second childhood (preceded by a real childhood). However, after implementation of enhancing techniques we end up in a further transitory state and that can be called a third childhood. The latter is then a starting point to a fourth childhood and so on. N. Agar presents that sequence of consecutive transformations in the following way:

"Childhood $\rightarrow$ Second Childhood (Human Adulthood) $\rightarrow$ Third Childhood (Posthuman Adulthood) $\rightarrow$ Fourth Childhood $\rightarrow$... nth Childhood $\rightarrow$..."(Agar 2014: 77).

Thus, what we can be sure about is a constant flow of radical transformations we will be subject to; but we cannot attain a conceptual clarity as to who we finally become and, consequently, what that state will be all about.

Agar supplements that telling picture with additional considerations. He points out that in the course of a normal childhood children are under supervision of parents, foster parents and educators. The latter know how to assist the former and help them to attain adulthood safely and responsibly. Parents and educators possess adequate knowledge and experience because they themselves have experienced childhood and a passage to adulthood is behind them. Thus, they are usually trustworthy guardians in the process of upbringing. Let us apply this scheme to human enhancement debates and ask about analogous figures of leaders. Are they indeed among us ready to give us a hand? Do we have super-parents and super-educators among us? The answer is rather negative. Understandably N. Agar claims that "we lack radically enhanced guardians to ensure that what we do in this intermediate childhood does not preempt or prejudice the commitment and projects of our future posthuman adulthood" (Agar 2014: 75). Hence, we are unaware where we go while accepting radically enhancing procedures and there is no one able to assist us in this enterprise. As a result, we are not only facing a lack of clarity and guidance but we are actually facing a quite serious uncertainty concerning our future perspectives.

7 In this respect, a quite suggestive picture is provided by J. Harris. He reasons in the following way, "there are already, and in the future will increasingly be, all kinds of new creatures out there $\langle\ldots\rangle$. Some will be man-made (rather than man and woman made) resulting from something more akin to construction than sexual reproduction. They may result from synthetic gametes or so-called 'synthetic biology', but however synthetic their creation they will be real in every important sense" (Harris 2016: 49). 
For the ethics of human enhancement it brings with it some vital consequences: aims of radical enhancement as well as means cannot be unequivocally considered as positive; thus voicing a moral opposition to this enterprise is well grounded and rational.

What about less radical enhancements? Do they bring with them an analogous scale of uncertainties? Preliminarily we should shed some light on what "less radical enhancement" concept stands for. We can assume that some improvements can be carried out in such a way that concerned subjects do not lose their humanity. They remain within boundaries determined by parameters typical for the human family as known at present. Thus, less radical improvements are not intended, for instance, to radically prolong our lifespan, a level of intelligence and so on. They are rather embarked on in order to help people to better deal with various untypical existential difficulties. Let us point to two examples. Firstly, a level of human IQ intelligence is about 100; but there are people who are endowed with lower digits, say, 89. Those people are clearly in a disadvantaged situation in a contemporary society where they live in. Helping such individuals to upgrade their intelligence, say, up to 115 will give them a competitive edge in that society. At a certain point, such a move may be necessary because a complexity of techno-sphere is growing all the time and to deal properly with, for instance, new electronic devices demands a fair level of human intelligence.

Secondly, less radical enhancement can be associated with a situation of a sudden shift in the environment like an ecological crisis or other unexplained changes connected with conditions of the planet Earth. J. Harris provides us with a telling example of that: "suppose due to further depletions to the ozone layer, all white-skinned people were very vulnerable to skin cancer on even slight exposure to the sun, but brown- and black-skinned people were immune. We might then regard white people as suffering substantial disability relative to their darker-skinned fellows" (Harris 2016: 20). Understandably something must be done in order to strengthen white people's resistance and genetics and genetic engineering will have to be employed. Then, in a sense, it will live up to Harris' postulate of "taking evolution into human intelligent hands" with such an exception that an intended consequence does not bring about here a radical change but is an application of a feature which is already possessed by some human individuals. In short, getting more resistance in some vital respects, we do not leave the borderlines of humankind ${ }^{8}$.

The level of uncertainty is here much lower because we basically know what we want to obtain and we are practically familiar with situations when someone has a slightly higher level of IQ intelligence and when people exhibit more resistance to natural elements. Of course, some serious uncertainties may be associated with the means leading to those modifications, namely how safe they are. As for now, we do not practice on a large scale such interventions and consequently we do not know the probable negative side-effects associated with such a scenario. Thus, a low level of uncertainty concerning ends may be associated with a high level of uncertainty stemming from implementation of corresponding technical means ${ }^{9}$.

8 Of course, such a thesis presupposes that we value humankind and consequently human nature. If we feel that we should protect it, in some aspects, it means that human nature possesses some normative appeal. Even if that reasoning is not openly acknowledged, as it happens in many adherents of human enhancement, human nature is the value-laden and normative category (Hauskeller 2013: 87).

9 Today we do not have an adequate knowledge concerning the means of human enhancement because any such procedures are at the very early stage. Thus, it is nowadays difficult to assess precisely how safe they are and how moral is their implementation. However, the slippery-slope logic can be adapted here as a helpful tool. Thus, procedures that contain serious doubts - technical and even more moral - at the very outset of their applications should be forbidden in order to prevent some serious evils and dangerous consequences at further stages. 


\section{CONCLUSIONS}

What kind of narrative do we face while talking about human enhancement ethics? It has elements coming from both the above-mentioned accounts: it is relatively recent and appeals to human emotions and imagination, on the one hand; but on the other, it draws on well-established ideas of philosophy and exact sciences. Thus, human enhancement ethics seems to possess something of great narratives and of small ones. It occupies a place between these two and, depending on what is stressed, we stand before a creative continuation of well-established concepts and ideas or before a set of proposals having to do more with imagination and semi-scientific predictions ${ }^{10}$.

Human enhancement ethics is a kind of interplay of certainties and uncertainties. This may be perceived as an uncomfortable and troublesome situation, especially when it touches on important issues. However, a different assessment of that is also possible. Uncertainties may play roles of stimulating factors for further research and philosophical thinking. This may lead us to attaining a greater understanding of who we want to become in the future, and in what way. Thus, uncertainties can, at times, reach levels of certainties; unknowns can be made into the known. And even when such an optimistic scenario will not be carried out, the presence of uncertainties concerning our future destinies may help us to discover new horizons of our existence and lead us to understand better something which is given to us right now but not appreciated enough. This will take place particularly when we realize that some human enhancement expectations are unviable and even utopia-oriented and we should divert our gaze and penetrate more deeply into who we are and what we possess already.

Received 1 September 2017

Accepted 23 November 2017

\section{References}

1. Agar, N. 2014. Truly Human Enhancement. A Philosophical Defense of Limits. Cambridge (MA) and London: The MIT Press.

2. Bostrom, N. 2014. Super Intelligence. Paths, Dangers, Strategies. Oxford: Oxford University Press.

3. Glover, J. 2006. Choosing Children: Genes, Disability, and Design. Oxford: Oxford University Press.

4. Harris, J. 2007. Enhancing Evolution. The Ethical Case for Making Better People. Princeton and Oxford: Princeton University Press.

5. Harris, J. 2016. How to Be Good. The Possibility of Moral Enhancement. Oxford: Oxford University Press.

6. Hauskeller, M. 2013. Better Humans? Understanding the Enhancement Project. Durham: Acumen.

7. Holub, G. 2016. "Human Enhancement, the Person, and Posthuman Personhood", Ethics \& Medicine. An International Journal of Bioethics 32(3): 171-183.

8. Kamm, F. M. 2005. "Is There a Problem with Enhancement?", American Journal of Bioethics 5(3): 5-14.

9. Kurzweil, R. 2005. The Singularity Is Near: When Humans Transcend Biology. London: Viking Penguin.

10. Oxford English Dictionary. 2016. Word of the Year 2016 is... Available at: https://en.oxforddictionaries. com/word-of-the-year/word-of-the-year-2016 (cited 04.05.2017).

11. Persson, I.; Savulescu, J. 2012. Unfit for the Future. The Need for Moral Enhancement. Oxford: Oxford University Press.

12. Popper, K. 2002. The Logic of Scientific Discovery. London and NewYork: Routledge.

13. Postigo Solana, E. 2009. "Transumanesimo e postumano: principiteorici eemplicazionibioetiche", Medicina e Morale 2: 267-282.

${ }^{10}$ Arguments employed by philosophers and adherents of human enhancement are methodologically unclear. It seems that at times they have a hybrid-like character, namely that at the starting point of the reasoning there is some scientific data but conclusions rather have a philosophical character, and sometimes even a science fiction-like. Premisses of the latter are introduced in an unknown ways, probably they reflect the convictions of those philosophers. Understandably, these methodological moves amount to a kind of logical incompatibility. 
14. Ryan, M.-L. 2007. "Towards a Definition of Narrative", in The Cambridge Companion to Narrative, ed. D. Herman. Cambridge: Cambridge University Press, 22-35.

\title{
Žmogaus patobulinimo etika ir neaiškumai
}

\begin{abstract}
Santrauka
Straipsnyje svarstomi kai kurie su žmogaus patobulinimo etika susiję neaiškumai. Ši etika pristatoma kaip tam tikras naratyvas, sudarytas iš mokslinių ir filosofinių sąvokų. Svarstoma, kad mokslinès sampratos, kuriomis remiasi žmogaus patobulinimo tendencija, susiduria su rimtais neaiškumais, ypač kalbant apie radikalų patobulinimą. Filosofiniu lygmeniu turime reikalų su daugybe neišspręstų klausimų apie gèrio ir mūsų postžmogiškosios lemties supratimą - būtent apie tai, kuo ir kodẻl norime tapti. Dèl to kyla didžiulis neaiškumas. Tačiau neaiškumai nèra visai beverčiai arba destruktyvūs. Jie gali atlikti stimuliuojančių veiksnių vaidmenis arba bent jau pasitarnauti atrandant naujus mūsų egzistencijos horizontus. Kai kuriose situacijoje jie taip pat gali paskatinti suvokti ir įvertinti tai, ką mes jau turime.
\end{abstract}

Raktažodžiai: etika, naratyvas, neaiškumas, žmogaus lemtis, žmogaus patobulinimas 